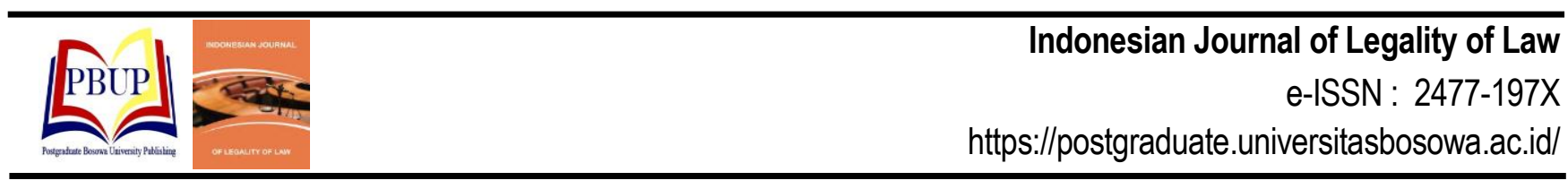

\title{
EFEKTIVITAS DOKTER KEPOLISIAN DALAM PEMBUKTIAN TINDAK PIDANA PEMBUNUHAN
}

\author{
The Effectiveness of the Police Doctors in Proving the Crime of Murder \\ Desy Natalia Salim ${ }^{1}$, Ruslan Renggong ${ }^{2}$, Baso Madiong ${ }^{2}$ \\ ${ }^{1}$ Kepolisian Daerah Sulawesi Barat \\ ${ }^{2,3}$ Program Studi Ilmu Hukum Program Pascasarjana Universitas Bosowa \\ Email: desynataliasalim@gmail.com
}

Diterima: 01 April 2020/Disetujui: 05 Juni 2020

\begin{abstract}
ABSTRAK
Penelitian ini bertujuan untuk mendiskripsikan sejauh mana Ilmu Kedokteran Forensik berperan pada pembuktian tindak pidana penghilangan nyawa di persidangan. Selain itu buat mengetahui pelaksanaan verifikasi tindak pidana pembunuhan atas dasar penerapan Ilmu Kedokteran Forensik. Metode pendekatan yg dipergunakan yaitu pendekatan Yuridis empiris yg menerapkan pendekatan berasal sudut kaidah-kaidah serta aplikasi peraturan yg berlaku pada warga serta dilakukan dengan meneliti data sekunder terlebih dahulu, kemudian dilanjutkan dengan mengadakan penelitian terhadap data primer yg terdapat pada lapangan. sesuai yang akan terjadi penelitian serta pembahasan, pelaksanaan verifikasi tindak pidana penghilangan nyawa atas dasar penerapan Ilmu Kedokteran Forensika dalah KUHP, KUHAP khususnya Pasal 184, UndangUndang RI nomor 23 Tahun 1992 perihal kesehatan, Undang-Undang RI angka 4 Tahun 2004 tentang Kekuasaan Kehakiman, yg kesemuanya memuat tentang dasar pertimbangan hakim dalam memutus suatu masalah, hal-hal yang mendukung diperolehnya verifikasi atas tindakan yang dilakukan terdakwa, serta keterangan-kabar yg diperoleh pada persidangan.
\end{abstract}

Kata Kunci : Polisi, Dokter, Pembuktian, Tindak Pidana Pembunuhan

\section{ABSTRACT}

This study aims to describe the extent to which Forensic Medicine approves the proof of the crime of murder in court. In addition, it aims to know the verification process for the follow-up implementation of the application of Forensic Medicine. The method uses empirical juridice that applies the requirements of the rules and application of regulations that apply to citizens and is done by connecting secondary data that is released, then proceeded with research examining primary data in the field. In accordance with what will occur, the research and discussion, as well as the implementation of verification of the sentence carried out on the basis of the application of Forensic Medicine is the Criminal Code, special Criminal Code Article 184, Republic of Indonesia Law number 23 of 1992 concerning health, Indonesian Law number 4 of 2004 concerning Power The judiciary, which agrees with the issue of judgment, matters that support the verification of the actions of the defendant, and the answers obtained at the trial.

Keywords: Police, Docter, Evidence, Crime of Murder

\section{PENDAHULUAN}

Penegakan hukum merupakan proses untuk mewujudkan keinginan-keinginan hukum menjadi kenyataan (Rahardjo, 1980). Hal ini menuntut peran masyarakat dalam berinteraksi sosial semakin meningkat karena aktivitas-aktivitas yang ada menjadi beragam, bahkan ada yang memancing adanya tindak kriminalitas yang bisa terjadi setiap hari. Peran penegak hukum jelasjelas tidak akan bisa lepas dari hal ini, sehingga menuntut diciptakannya berbagai macam peraturan untuk dapat menciptakan ketertiban dalam masyarakat.

Seiring dengan kemajuan ilmu pengetahuan dan teknologi bahwa orang yang mendapatkan pembuktian secara ilmiah disebut dengan saksi diam (silent witness). Oleh karena itu, diperlukan peran ahli dalam memeriksa barang bukti secara ilmiah sesuai dengan keahliannya tersebut (Amri, 2005; Andreoli dkk., 1997). Salah satunya adalah dokter yang selain bertugas sebagai tenaga medis, juga dituntut untuk memberikan bantuan kepada penegak hukum yang kita kenal dengan ahli forensik, teknologi informasi serta INAFIS (Indonesia Automatic Finger Print Identification System) atau Indentifikasi Tempat Kejadian Perkara (TKP).

Selanjutnya dalam tahap tindakan polisional yang meliputi penyelidikan dan penyidikan oleh aparat Kepolisian Republik Indonesia guna mencari kebenaraan materiil, atau untuk dapat mengatasi tindak kejahatan mulai dari yang tradisional hingga yang memanfaatkan kemajuan iptek, dikenal adanya metode Penyidikan Berbasis Ilmiah (Scientific 
Crime Investigation). Cara yang dapat dilakukan untuk pembuktian perkara pidana antara lain adalah meminta bantuan dokter sebagai saksi yang dapat membuat keterangan tertulis dalam bentuk visum et repertum dan memberikan keterangan dipersidangan sebagai saksi ahli. Artinya, bahwa ilmu pengetahuan kedokteran sangat berperan dalam membantu penyidik, kejaksaan, dan hakim dalam hal yang hanya dapat dipecahkan dengan ilmu kedokteran.

Hal ini sesuai Undang-Undang No. 2 Tahun 2002 Pasal 14 tentang Kepolisian Negara Republik Indonesia menyebutkan salah satu tugas kepolisian adalah melakukan penyidikan. Penyidikan diatur dalam Undang-Undang No. 8 Tahun 1981 tentang Kitab Undang-Undang Hukum Acara Pidana, dalam Pasal 1 ayat (2) yang menjelaskan bahwa penyidikan adalah serangkaian tindakan penyidik dalam hal dan menurut cara yang diatur dalam undangundang ini untuk mencari serta mengumpulkan bukti yang terjadi dan guna menemukan tersangkanya. Polri juga diamanatkan untuk melakukan identifikasi, laboratorium forensik dan psikologi untuk tugas kepolisian, penjabarannya melakukan olah Tempat Kejadian Perkara (TKP) secara ilmiah untuk mengungkap kasus pidana. Oleh karena itu, berdasarkan uraian di atas, penulis teratrik untuk mengkaji lebih lanjut tentang Peran Dokter Kepolisian dalam membantu mengungkap suatu kasus pembunuhan.

\section{METODE}

Penelitian ini menggunakan deskriptif-kualitatif untuk dapat menggambarkan atau melukiskan objek penelitian berdasarkan fakta-fakta yang tampak atau sebagaimana adanya, yang mana menjelaskan tentang bagaimana peranan Dokter Kepolisian (DOKPOL) dalam Pembuktian Tindak Pidana Pembunuhan. Adapun metode pendekatan yang digunakan yaitu pendekatan yuridis-empiris yang menerapkan pendekatan dari sudut kaidah-kaidah dan pelaksanaan peraturan yang berlaku di masyarakat dan dilakukan dengan meneliti data sekunder terlebih dahulu, kemudian dilanjutkan dengan mengadakan penelitian terhadap data primer yang ada di lapangan.

Data yang diperoleh ditempuh dengan menggunakan teknik pengumpulan berupa penelitian kepustakaan dimana data yang diperoleh dari membaca dan memahami buku-buku literatur serta pengaturan-pengaturanyang relevan dengan permasalahan yang dibahas, sebagai data sekunder yang mencakup bahan hukum primer yang terdiri dari bahan yang memberikan penjelasan mengenai bahan hukum primer seperti hasil penelitian, makalah seminar, artikel surat kabar atau majalah, dan lain-lain. Bahan hukum sekunder yaitu norma atau kaedah dasar, peraturan dasar, peraturan perundangundangan, yurisprudensi. Peraturan dasar dari peraturan perundang-undangan diambil dari Undang- undang nomor 2 Tahun 2002 Tentang Kepolisian Negara Republik Indonesia, Undang-undang No 8 Tahun 1981 Tentang Kitab Undangundang Hukum Acara Pidana, PP No 58 Tahun 2010 Tentang Pelaksanaan Kitab Undang-undang Hukum Acara Pidana, Peraturan KAPOLRI No.2Tahun 2010 tanggal 30 September 2010 tentang Susunan Organisasi dan Tata Kerja Satuan Organisasi Pada Tingkat Markas Besar Kepolisian Negara Republik Indonesia, dan peraturan sejenis serta buku-buku yang dimiliki oleh Biddokkes Polda Sulsel.

Data yang dikumpulkan dari hasil penelitian baik data primer maupun data sekunder, selanjutnya dianalisis secara kualitatif dan dibahas dalam bentuk penjabaran dengan memberi makna sesuai peraturan perundang-undangan yang berlaku.

\section{HASIL DAN PEMBAHASAN}

Salah satu delik formil yang menekankan pada perbuatan yang dilarang oleh suatu aturan hukum adalah tindak pidana pembunuhan, ancaman yang dihadirkan dari larangan atau sanksi yang berupa pidana menanti para pelaku tindak pidana untukdiperhadapkan di depan hukum. Pelaku tindak pidana akan dimintai pertanggung jwaban di depan hukum atas perbuatan tindak pindana yang dilakukannnya seusai dengan aturan yang berlaku. Ancaman pidana menannti siaspa saja yang berani melakukan tindak pidana. Demi mampu menuntut siapa pelaku tindak pidana pembunuhan diperlukan pembuktian sebagaimana diataur dalam Pasal 183 dan Pasal 184 Kitab Undang-Undang Hukum Acara Pidana (KUHAP), dalam pencarian bukti-bukti awal menjadi suatu hal mutlak dilakukan untuk mencari tahu sebab muasal tindak pidana.

Hukum acara pidana yang berlaku di Indonesia pada saat ini adalah Undang-Undang Nomor 8 tahun 1981 tentang Hukum Acara Pidana, yang lazim disebut KUHAP yang diundangkan pada tanggal 31 Desember tahun 1981. Hukum acara pidana atau hukum formil adalah kumpulan peraturanperaturan yang mengatur tata cara atau prosedur penyelenggaraan atau penegakan hukum pidana materil oleh alat-alat negara di muka pengadilan pidana (Poernomo, 1982). Menegakkan keadilan lewat lembaga peradilan selalu menyandang konsekuensi mengorbankan tersangka/terdakwa untuk menjadi objek pemeriksaan (Widhayanti, 1988). Hal ini disebabkan oleh adanya ketidakseimbangan posisi tawar tersangka dengan para penegak hukum, yang dalam hal ini diwakili oleh para penyidik, baik dari segi psikologis maupun hak dan kewajibannya sehingga sulit untuk mendapatkan suatu kebenaran yang murni dan objektif.

Hakim dalam persidangan tindak pidana benar-benar menggali sebuah kejadian demi mendapatkan informasi yang jelas atas terjadinya suatu tindak pindana. Kejelian hakim dalam mencari sebuah fakta kebenaran dalam persidangan melalui pemeriksaan yang sangat teliti adalah sebuah keharusan untuk mendapatkan serta mendakwakan pelakku tindak pidana untuk dihukum seusai dengan undang-undang yang telah diatur. Dalam peradilan, apabila hakim diperhadapkan pada kasus yang berkitan dengan luka, maka dokter forensik memiliki rperan dalam pengungkapan kasus untuk menelaah barang bukti yang dapat berupa tubuh atau bagian dari tubuh manusia.

Pasal 183 Undang-undang Nomor 8 tahun 1981 menyatakan bahwa hakim tidak boleh menjatuhkan sanksi pidana pada seseorang apabila tanpa dengan sekurangkurangnya dua alat bukti yang sah. Adapun pada Pasal 184 KUHAP menyatakan bahwa alat bukti yang sah adalah keterangan saksi, keterangan ahli, surat, petunjuk, dan keterangan terdakwa. Apabila suatu proses pemeriksaan persidangan perkara pidana hakim yang melakukan pemeriksaan persidangan tanpa adanya alat bukti, hakim tidak akan dapat mengetahui dan memahami apakah suatu tindak pidana telah terjadi dan apakah terdakwa benar-benar telah melakukan tindak pidana dan bertanggung jawab atas suatu peristiwa pidana (Hartanto dan Murofiqudin, 2001). Olehnya itu, keberadaan alat bukti harus menjadi suatu landasan, bilamana peradilan diperhadapkan dengan kasuskasus yang berkaitan dengan luka, dokter forensik memiliki 
bperan dalam pengungkan fakta hukum melalui barang bukti yang dapat berupa tubuh atau bagian dari tubuh manusia. Peranan dokter forensik untuk pembuktian perkara pidana hukum acara pidana memiliki tujuan mencari kebenaran materil dari sebuah peristiwa pidana. Penemuan kebenaran materil tidak lepas dari adanya pembuktian yang mengilustrasikan tentang bagaimana kejadian yang konkrit. Kejadian konkrit demikian yang dapat menjadi pembuktian tentang sesuatu menurut hukum pidana berarti petunjuk halhal yang mampu ditangkap oleh panca indra, menggambarkan hal tersebut serta berfikir secara logika.

Dengan berdasar pada hasil pemeriksaan dokter forensik inilah selanjutnya mampu diketahui apakah luka seorang, tidak sehat atau tidaknya seseorang tersebut diakibatkan oleh suatu tindak pidana atau tidak. Dokter ahli forensik bisa memberikan bantuannya sekaitan dengan proses peradilan dalam hal pemeriksaan di tempat terjadinya perkara, ini bisa dimintakan oleh pihak yang berwajib dalam hal dijumpai seseorang yang ditemukan dalam keadaan meninggal dunia. Pemeriksaan yang dilakukan dokterr forensik sangat penting dalam hal menentukan jenis kematian serta dapat mengetahui sebab-sebab dari kematian seseorang, baik digunakan oleh pihak yang berwajib untuk memproses atau tidak memproses menurut hukum. Dalam hal ini ahli forensik akan membuat visum et repertum sebelum jasad dikuburkan. Adapun pemeriksaan terhadap korban yang luka oleh dokter forensik bermaksud untuk mengetahui ada atau tidaknya penganiayaan, menentukan terjadi atau tidaknya kejahatan atau pelanggaran kesusilaan, untuk mengetahui usia seseorang, dan untuk menentukan kepastian seorang bayi yang meninggal dalam kandungan seorang ibu. Berdasar hasil pemeriksaan ahli forensik dapat disimpulkan bahwa ahli forensik memiliki peran dalam mengungkap serta membantu aparat penegak hukum untuk mengungkap terjadinya tindak pidana yan mulai dari tingkat penyidikan sampai pada tahap pengadilan terhadap kasus yang berkaitan dengan tubuh atau jiwa manusia, sehingga dapat membuat keterangan tentang terjadinya suatu tindak pidana yang dialami oleh kedokteran kehakiman dalam pembuktian tindak pidana pembunuhan

Dokter sebagai pembuat Visum Et Repertum (VeR) dimana keterangan tertulis yang dibuat dokter atas permintaan penyidik yang berwenang mengenai hasil pemeriksaan medis terhadap manusia, hidup ataupun mati, ataupun bagian/diduga bagian tubuh manusia, berdasarkan keilmuannya dan di bawah sumpah untuk suatu kepentingan peradilan (Monita dan Dheny, 2013). VeR sangat berperan menjadi salah satu alat bukti yang sah untuk proses pembuktian dalam perkara pidana terhadap kesehatan dan jiwa manusia. Dalam VeR diuraiakan mengenai hasil pemeriksaan medis yang tertuang pada bagian pemberitaan, karenanya dapat dianggap sebagai pengganti barang bukti. VeR juga memuat keterangan pendapat dokter mengenai hasil pemeriksaan medis yang dituangkan pada bagian kesimpulan. Apabila VeR belum dapat menerangkan persoalan pada persidangan, hakim bisa meminta keterangan ahli untuk diajukannya bahan baru, seperti yang tercantum dalam Kitab Undang-undang Hukum Acara Pidana (KUHAP), yang memberi kemungkinan diadakanna pemeriksaan atau penelitian ulang pada barang bukti, apabila muncul keberatan yang beralasan dari terdakwa atau penasehat hukumnya pada suatu hasil pemeriksaan.

Visum et repertum dibuat berdasarkan Undang-Undang yaitu pasal 120, 179, dan 133 ayat 1 KUHAP, dokter forensik tidak dapat dituntut karena membuka rahasia pekerjaan sebagaimana diatur dalam pasal 322 KUHP, meskipun dokter membuatnya tanpa seizin pasien. Pasal 50 KUHP menyatakan bahwa barang siapa melakukan perbuatan untuk melaksanakan ketentuan undang-undang, tindakk dipidana, sepanjang visum et repertum tersebut hanya dapat diberikan kepada instansi penyidik yang memintanya, untuk selanjutnya dipergunakan dalam pembuktian pada proses pengadilan. Seperti diketahui dalam suatu perkara pidana yang menyangkut pengrusakan tubuh dan kesehatan serta menghilnagkan nyawa manusia, maka tubuh manusia atau korban tersebut sebagai Corpus Delicti. Oleh karenanya itu, Corpus Delicti sangatlah tidak mungkin dihadirkan atau diajukan di depan persidangan dan secara mutlak digantikan dengan VeR.

Kedudukan seorang dokter dalam penanganan korban kejahatan dengan menerbitkan VeR seharusnya disadari dan dijamin netralitasnya, karena bantuan profesi dokter akan sangat menentukan adanya kebenaran (Monita dan Dheny, 2013). Sekaitan dengan peran VeR yang sangat vital dalam mengungkap suatu kasus tindak pidana yang bertalian dengan tubuh manusia, seperti ppada kasus perkosaan, pengaduan atau laporan pada institusi Kepolisian baru akan dilakukan apabila tindak pidana perkosaan telah berlangsung lama sehingga tidak diketemukan lagi tanda-tanda kekerasan pada diri korban. Bila korban dibawa ke dokter untuk mendapatkan pertolongan medis pertama, maka dokter berkewajiban untuk melaporkan kasus pemerkosaan ke polisi atau menyarankan keluarga korban untuk melapor kepolisian. Korban yang melapor terlebih dahulu ke pihak polisi nantinya akan dibawa ke dokter untuk mendapatkan pertolongan medis sekaligus pemeriksaan forensik agar dibuatkan visum et repertumnya. Oleh sebab itu, sebagai dokter forensik memiliki tugas untuk memeriksa dan mengumpulkan berbagai bukti yang berhubungan dengan pemenuhan unsur-unsur delik seperti yang dinyatakan oleh undang-undang, dan menyusun laporan VeR.

Bantuan seorang ahli sangat dibutuhkan pada suatu proses pemeriksaan perkara pidana, baik pada tahap pemeriksaan pendahuluann dan maupun pada tahap pemeriksaan lanjutan di sidang pengadilan, mempunyai peran dalam membantu aparat yang berwenang untuk menerangkan suatu perkara pidana, mengumpul bukti-bukti yang memerlukan keahlian khusus, memberikan petunjuk yang lebih kuat tentang pelaku tindak pidana, implikasinya membantu hakim dalam menjatuhkan putusan yang tepat mengenai perkara yang diperiksanya. Ditahap pemeriksaan pendahuluan dimana telah dilakukan proses penyidikan atas terjadinya suatu peristiwa yang dicurigai sebagai suatu tindak pidana, tahapan ini memiliki peran yang cukup penting untuk menentukan tahap pemeriksaan selanjutnya dari keseluruhan proses di peradilan pidana. Tindakan penyidikan yang dilakukan oleh pihak Kepolisian bertujuan untuk mencari dan mengumpulkan bukti. Dengan bukti tersebut mampu membuat terang suatu tindak pidana yang terjadi untuk menemukan tersangkanya. Dengan berdasar pada hasil yang didapat dari tindakan penyidikan suatu kasus perkara pidana, hal ini selanjutnya diproses pada tahap penuntutan dan di muka persidangan pengadilan.

Dokter yang merupakan aparatur sipil negara yang memiliki kewajiban untuk mengabdi kepada kepentingan masyarakat banyak dan Negara. Dokter dalam pengertian 
yang sangat luas, tidak boleh melakukan penolakan terhadap kewajiban. Menolak untuk melakukan kewajiban yang telah diamanatkan berarti melanggar undang-undang. Berdasar hal tersebut, apabila kita melihat di dalam KUHAP ada beberapa ketentuan yang mengatur tentang saksi ahli diantaranya yaitu Pasal 1 butir (28) yang menegaskan bahwa keterangan ahli adalah keterangan yang diberikan oleh seorang yang memiliki keahlian khusus tentang hal yang diperlukan untuk membuat terang suatu perkara pidana guna kepentingan pemeriksaan. Pada pasal 120 ayat (1) yang menerangkan bahwa dalam hal penyidik menganggap perlu bantuan, penyidik dapat minta pendapat orang atau ahliorang yang memiliki keahlian khusus dalam pengungkapan kasus. Adapun pasal 133 ayat (1) bahwa dalam hal ini, penyidik untuk kepentingan peradilan menangani seorang korban, baik luka, keracunan ataupun meninggal dunia patut diduga disebabkan oleh peristiwa kejahatan tindak pidana, penyidik memiliki kewenangan untuk mengajukan permintaan keterangan ahli kepada ahli kedokteran kehakiman atau dokter dan atau ahli lainnya. Berikutnya pasal 179 ayat (1) bahwa Setiap orang yang diminta pendapatnya sebagai ahli kedokteran kehakiman atau dokter atau ahli lainnya wajib memberikan keterangan ahli demi keadilan".

Dengan berdasar penjelasan sebelumnya, dapat diterangkan bahwa saksi ahli adalah seorang dokter, baik itu dokter ahli ilmu kedokteran kehakiman ataupun ahli lainnya, di dalam penjelasan Pasal 133 KUHAP disebutkan, bahwa yang dapat memberi keterangan ahli adalah ahli ilmu kedokteran kehakiman, sehingga dengan demikian, teranglah berdasar pada pasal 133 KUHAP bahwa dokter umum tidak termasuk dari bagian saksi ahli namun hanya sebatas memberikan keterangan tentang suatu peristiwa. Namun bila ditelaah lagi mengenai bunyi Pasal 133 KUHAP dengan jelas menyatakan bahwa penyidik memliki kewengan untuk mengajukan permintaan keterangan ahli kepada ahli kedokteran kahakiman, dokter ahli lainnya. Oleh karena itu, uraian di atas cukup jelas bahwa bunyi Pasal 133 KUHAP tidak sejalan dengan penjelasannya.

Pada masalah permintaan bantuan seorang saksi ahli hanya dapat diajukan secara tertulis dengan menyebutkan jenis bantuan yang akan dilakukan atau pemeriksaaan yang diminta. Misal, kasus tindak pidana kekerasan yang mengakibatkan korban meninggal dunia, maka penyidik dapat melakukan permintaan bantuan terhadap saksi ahli dalam hal ini saksi ahli forensik, bantuan apa yang dibutuhkan untuk dijadikan sebagai barang bukti tertulis maupun lisan, dan batasan pemeriksaan yang dilakukan oleh ahli forensik apakah sebatas pemeriksaan luar (pemeriksaan fisik) ataukah juga pemeriksaan luar dan dalam (autopsi). Keterangan saksi ahli dapat disebut sebagai alat bukti yang sah dalam pengungkapan fakta pada persidangan di pengadilan dapat berupa secara Tertulis (Visum Et Repertum) juga secara lisan. Saksi ahli mempunyai peranan tyang sangat penting untuk berfungsi dalam pengungkapan fakta di pengadilan.

Proses pembuktian pada persidangan yang menghadirkan keterangan saksi ahli dapat digolongkan menjadi beberapa macam, yaitu sebagai alat bukti yang terbagi menjadi2 (dua) kategori yaitu surat dan keterangan ahli, menjadi keterangan yang disamakan nilainya dengan alat bukti, sebagai keterangan penguat keyakinan hakim, dan menjadi keterangan yang tidak berfungsi apa-apa.

Pasal 179 ayat (1) KUHAP menyatakan bahwa setiap orang yang diminta pendapatnya sebagai ahli kedokteran kehakiman atau dokter atau ahli lainnya wajib memberikan keterangan ahli demi keadilan". Penjelasan pasal 133 ayat (2) menyatakan bahwa keterangan ahli yang diberikan oleh ahli kedokteran kehakiman disebut keterangan ahli, sedangkan keterangan yang diberikan dokter bukan ahli kedokteran kehakiman disebut keterangan dan pasal 187 huruf c menyatakan bahwa salah satu alat bukti surat adalah surat keterangan dari seorang ahli yang memuat pendapat berdasarkan keahliannya mengenai suatu hal atau suatu keadaan yang diminta secara resmi kepadanya". Dari penjelasan di atas dapat dikelompokkan 2 (dua) bentuk alat bukti yang berasal dari keterangan ahli, yaitu alat bukti surat (visum et repertum) dan alat buktii keterangan ahli.

Penjelasan di atas menerangkan bahwa istilah "saksi ahli" acapkali digunakan dalam proses peradilan, hal tersebut sangatlah tidak tepat, demkian itu dikarenakan menjadi alat bukti keterangan saksi, seorang ahli yang tidak memenuhi kriteria seorang saksi seperti yang diatur pada pasal 1 angka 26 KUHAP. Pada perkara pidana, secara formil kekuatan pembuktian oleh keterangan ahli tidak dapat mengikat dan memengaruhi putusan hakim. Sejalan dengan sistem pembuktian yang dianut dalam peradilan pidana di Indonesia, yakni pembuktian menurut undang-undang secara negatif. Hakim bebas menilainya sebagai fakta persidangan, penguat atau tidak untuk keyakinan hakim dan tidak terikat kepada keterangan ahli. Pada perkara dugaan malpraktik medik, yang dilakukan oeh tenaga medik, keterangan ahli mempunyai peranan yang vital menentukan, serta menjelaskan karena dari keterangan serta penjelasan yang diberikannya dapat memuat terang apakah sang dokter telah melakukan kewajiban dengan benar atau malah tidak sesuai prosedur. Secara materil seharusnya keterangan ahli yang dengan keahlian khusus dalam perkara pidana mempunyai kekuatan pembuktian yang mengikat.

Terkait dengan bantuan keterangan ahli yang atas dasar permintaan penyidik diperlukan dalam proses pemeriksaan suatu perkara tindak pidana, bantuan ini memiliki peran yang sangat penting demi mengungkap dan mengumpulkan buktibukti dalam usahanya menemukan kebenaran materiil suatu perkara tindak pidana. Berbagai kasus-kasus tertentu, penyidik sangat bergantung pada keterangan yang diberikan oleh ahli untuk mengungkap sejauh mana suatu peristiwa pidana yang sedang ditanganinya. Kasus-kasus tindak pidana seperti pembunuhan, penganiayaan dan perkosaan merupakan contoh nyata dimana kasus yang ditangani penyidik sangat membutuhkan bantuan tenaga ahli seperti dokter ahli forensik atau dokter ahli lainnya, demi memberikan keterangan medis tentang keadaan korban yang selanjutnya cukup berpengaruh bagi tindakan yang akan diambil penyidik dalam mengungkap lebih lanjut kasus yang ditangani

Suatu kasus yang dapat menunjukkan kinerja pihak Kepolisian selaku aparat penyidik membutuhkan keterangan ahli dalam tindakan penyidikan yang dilakukannya yaitu pada pengungkapan kasus pembunuhan. Kasus kejahatan terhadap suatu jiwa yaitu dengan menghilangkan nyawa seseorang baik dengan menggunakan senjata tajam atau benda tumpul, dibunuh ataupun bunuh diri, membutuhkan bantuan keterangan ahli dalam penyidikannya (Monita dan Dheny, 2013). Keterangan ahli yang dimaksud ini yaitu keterangan dari dokter yang dapat membantu penyidik untuk memberikan bukti fakta hukum berupa keterangan medis yang sah dan meyakinkan serta dapat dipertanggungjawabkan mengenai kondisi korban, terutama terkait dengan kekuatan pembuktian pada adanya tanda-tanda telah dilakukannya suatu tindak 
pidana pembunuhan yang dilakukan dengan benda tajam atau benda tumpul.

Hambatan yang seringkali ditemui adalah berasal dari keluarga atau kerabat korban itu sendiri. Setiap keluarga korban tindak pidana salah satunya pembunuhan biasanya merasa tiidak tega terhadap korban apalagi bila dilakukan autopsi, sehingga hal tersebut dapat menyebabkan proses penyidikian ynag dilakukan oleh dokter ahli untuk melakukan tindakan medis dalam rangka projustitia, dalam hal ini melalui penerapan ilmu Kedokteran Forensik untuk membuktikan tentang ada atau tidaknya kausa dalam terjadinya tindak pidana pembunuhan menjadi sulit.

\section{KESIMPULAN}

Hasil penelitian dan pembahasan dapat disimpulkan bahwa peranan dokter forensik dalam pembuktian perkara pidana yaitu membantu aparat penegak hukum baik dari tahap penyidikan sampai pada tahap persidangan terhadap tindak pidana yang berhubungan dengan tubuh atau jiwa manusia sehingga membuat terang peristiwa pidana tersebut, selanjutnya dokter forensik juga berperan dalam hal membuat Visum et repertum merupakan suatu laporan tertulis dari dokter (ahli) yang dibuat berdasarkan sumpah, mengenai apa yang dilihat dan ditemukan. Peranan Dokter Forensik, Pembuktian Pidana140 bukti hidup, mayat atau fisik ataupun barang bukti lain, kemudian dilakukan pemeriksaan menurut pengetahuannya. Adapun sebagai saksi ahli sebagaimana yang disebutkan dalam Pasal 1 butir 28 KUHP yaitu keterangan ahli adalah keterangan yang diberikan seseorang yang memiliki keahlian khusus tentang hal yang diperlukan untuk membuat terang suatu perkara tindak pidana. Dalam pembuktian perkara pidana yang berkaitan dengan tubuh atau jiwa manusia dokter foresik mempunyai peranan yang sangat penting untuk membantu hakim dalam mengungkap peristiwa pidana.

\section{DAFTAR PUSTAKA}

Amir, A., 2005, Rangkuman Ilmu Kedokteran Forensik Edisi Kedua, Ramadhan, Medan.

Andreoli, T. E., Kamus Kedokteran Dorland Edisi 29, Kedokteran EGC, Jakarta.

Hartanto dan Murofiqudin, 2001, Undang-Undang Hukum Acara Pidana Indonesia dengan Undang-Undang Pelengkapny, Muhammadiyah University Press, Surakarta.

Monita, Y. dan Dheny W., 2013, Peranan Dokter Forensik dalam Pembuktian Perkara Pidana, Universitas Jambi, Jambi.

Poernomo, B., 1993, Asas-asas Hukum Pidana, Ghalia Indonesia, Bandung.

Rahardjo, S., 1980, Hukum dan Masyarakat, Angkasa, Bandung.

Setiana, R. D., 2016, Kontribusi Scientific Crime Investigation (Penyidikan Berbasis Ilmiah) sebagai Upaya Penguatan Alat Bukti dalam Proses Penanganan Perkara Pidana. Fakultas Hukum Universitas Brawijaya, Malang.

Widhayanti, E., 1988, Hak-hak Tersangka/Terdakwa dalam KUHP, Liberty, Yogyakarta. 